\title{
Leadership styles of Iranian Physical Education teachers
}

\section{Estilos de liderazgo de profesores de Educación Física iraníes}

\author{
Manoochehr Houshyar', Sayed Hamid Sajadi², Abdolreza Amirtash², and Zahra Haji Anzahaei ${ }^{2}$ \\ 1 Department of Central Tehran Branch, Islamic Azad University, Tehran (Iran). \\ 2 Department of Sport Management, Central Tehran Branch, Islamic Azad University, Tehran (Iran).
}

\begin{abstract}
The present study aimed to determine the most adequate leadership style for Iranian Physical Education teachers. The sample was composed of 384 Physical Education teachers from Iran of 4 regions and 20 provinces. Multistage sampling and simple random sampling were used. The variables studied in this research were: 1) Leadership style. 2) Sociocultural attitudes. 3) Personality dimensions. 4) Situational factors. The leadership style was evaluated with the Likert Leadership Styles Standard Questionnaire. The sociocultural attitudes of the physical education teachers were determined with the Cultural Attitudes Questionnaire. The personality traits of the educators were analysed with the Five Personality Trait Inventory. The situational factors of employees were assessed with the Standard Staff Readiness Questionnaire. The final model of the appropriate leadership style with personality traits, cultural attitudes and situational factors of Physical Education teachers indicates that the most appropriate leadership styles for the Iranian Physical Education teachers were Delegating and Coaching styles, followed by Supporting and Directing styles.

Keywords: Leadership style; Physical Education; Teachers; Iran.
\end{abstract}

Resumen: El presente estudio tuvo como objetivo determinar el estilo de liderazgo más adecuado para los profesores iraníes de educación física. La muestra estuvo compuesta por 384 docentes de educación física de Irán de 4 regiones y 20 provincias. Se utilizó muestreo polietápico y muestreo aleatorio simple. Las variables estudiadas en esta investigación fueron: 1) Estilo de liderazgo. 2) Actitudes socioculturales. 3) Dimensiones de la personalidad. 4) Factores situacionales. El estilo de liderazgo se evaluó con el Cuestionario Estándar de Estilos de Liderazgo. Las actitudes socioculturales de los profesores de educación física se determinaron con el Cuestionario de Actitudes Culturales. Los rasgos de personalidad de los educadores se analizaron con el Inventario de los Cinco Rasgos de Personalidad. Los factores situacionales de los empleados se evaluaron con el Cuestionario Estándar de Preparación del Personal. El modelo final del estilo de liderazgo apropiado con rasgos de personalidad, actitudes culturales y factores situacionales de los profesores de Educación Física indica que los estilos de liderazgo más apropiados para los profesores iraníes de Educación Física fueron los estilos de Delegación y Entrenamiento, seguidos por los estilos de Apoyo y Dirección.

Palabras clave: Estilo de liderazgo; Educación Física; Docentes; Irán.

\section{Introduction}

Nowadays, organizations form the pivot of the current society. Two of the most important and vital factors of the organizations are management and people. The former is the most important factor in the life, growth, development, or death of the organization. The latter are the main organizers of each organization (Alvani, 2001). Organizations have found that their main assets are human resources and management of these resources is one of their most sensitive tasks (Rezaeian, 2001). In each organization, one of the vital pillars is the leadership. In the organization, a leader is one who can control factors such as: individual rights, working conditions, policies of the organization, identification, progress, and responsibility. In fact, how the leader can control these factors and how motivates the staff, reflects if the leader is effective (Reunanen and Kaitonen, 2017). That is why it is expected that the person who is the leader of an organization necessarily perform all the duties of a manager. Without leadership or guidance, the connection between the individual and organizational goals may be weakened or ruptured (González-Cruz, Botella-Carrubi, \& MartínezFuentes, 2019). This can lead to an unfavourable situation

Dirección para correspondencia [Correspondence address]: Sayed Hamid Sajadi. E-mail: Hamidsadjadi@gmail.com in which the entire organization loses its efficiency and ability to achieve its goals.

One of the definitions that can be given to leadership is that "leadership is the art or the science of influencing individuals in a way that they can take steps willingly to achieve their goals" (Parhizgar, 1989). As it was reported by Fiedler \& Shimmer (1993), the first research on leadership was published in 1904. According to Woods (2019), the management style is the special interpretation and mode of operation of the manager. An effective manager should be able to prevent possible problems and take adequate actions to solve them (Richardson, 2018). According to the needs, theories, styles and models of leadership and management have evolved, and managers should decide what style is the best and the most useful for the different situations (Alvani, 2001; Mujtaba, \& Sungkhawan, 2009).

Situational leadership theory is based on the principle that the "best" leadership style depends on the situation. Effective leadership depends on the desired task, and the most successful leaders are those who can adapt their leadership style to different situations. Effective leadership depends not only on the individual or group under the leadership of the leader, but also on the self-assignment and the work to be accomplished (Hersey and Blanchard, 1969, 1977). The leadership model of Hersey and Blanchard is based on two fundamental principles: lea- 
dership style and maturity of an individual or group. The four leadership styles used in the Situational Leadership Model are:

1) Directing: In this style, there is a one-way relationship between the leader and the follower. In this case, the leader will outline the roles of the individual or group and determine details such as how to do the assignment, its time and place.

2) Coaching: In this style, the leader identifies the course of the task. However, there is a two-way relationship between the leader and the follower, with social and emotional support, which causes that the individual or the group accept the process of performing the assignment.

3) Supporting: In this style, decisions are made with the purpose of doing the assignment jointly, and the leader determines the manner in which the assignment is carried out, while at the same time there will have a strong relationship with the followers.

4) Delegating: In this style, the leader is also involved in decision making. Nevertheless, the process and responsibility for the implementation of the assignments are fully deposited in the followers. In this case, the leader will monitor the process of implementation. (Hersey and Blanchard, 1977).

Hamdan (2009), while trying to design an appropriate leadership model for the management of Lebanese organizations (hospital management), came to the conclusion that the model adopted was consistent with both the internal factors governing the hospital and the personality of its leaders and cultural dimensions. According to this model, there was a direct and significant relationship between supportive leadership style and factors of masculinity, individualism and employee empowerment. Also, participatory leadership style was associated with factors of staff power distance and motivation, and directional leadership style with extroverted per- sonality. Sami'i (2010), studying the effect of teachers' needs on the effectiveness of leadership styles of elementary school principals, showed that teachers' needs are a factor that influences the relationship between leadership style and leader effectiveness. Elzami (2012) examined the relationship between principals' leadership styles and organizational learning in the high schools of Ray city, concluding that there is a meaningful and positive relationship between participatory, transactional, ethical, postmodern and managerial leadership styles with organizational learning. Vandayani, Kartini, Hilmiana (2015) examined the effect of national culture on leadership effectiveness and concluded that national culture had a significant effect on leadership effectiveness. Henkel \& Bourdeau (2018) studied the leadership style of military executives participating in the Advanced Leadership Training Program in the United States, and the results of the study showed that two situational leadership styles were predominant: advisory and participatory.

Leadership styles are also very important in education. Teaching and education of students is complex and needs to be effective, including the effectiveness of teachers. Physical Education and physical activity play a very important role in the education of future generations (Alamdari, \& Abdi, 2019; González, Nicolás, \& López, 2020; López et al., 2019; Nicolás, González, \& López, 2020; Sánchez, Cepeda, Díaz, Smith, \& López, 2019; Sánchez, López, Sgroi, \& Díaz, 2019), and therefore, Physical Education teachers should use the most appropriate leadership styles in the different situations in order to achieve the best learning results of the students. Several factors influence in the election of an appropriate leadership model, such as internal factors, situational factors, the character of the leaders and their cultural dimensions (Fani, Hamdan, Khayef, 2010; Hamdan, 2009; Sami'I, 2010). Considering all these factors, Figure 1 shows our conceptual model of appropriate leadership style of Physical Education teachers.

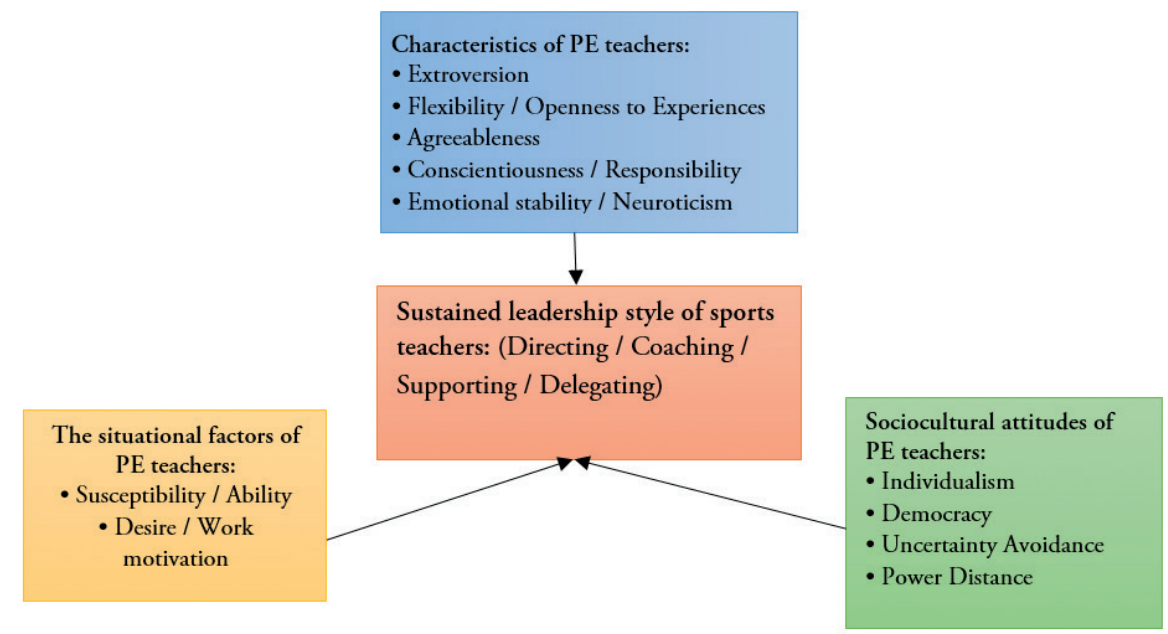

Figure 1. Conceptual Model of Appropriate Leadership Style of Physical Education Teachers. 


\section{Methods}

\subsection{Participants}

The current study was descriptive and correlational. Multistage sampling and simple random sampling were used. The sample was composed of 384 physical education teachers from Iran. The sample was distributed in 4 regions (North, South, Centre, East, West) and 20 provinces (4 provinces of each region). In each province, physical education teachers were randomly and proportionally selected. Table 1 shows the regions, the provinces, and the number of participants.

Table 1. Regions, provinces, and number of participants.

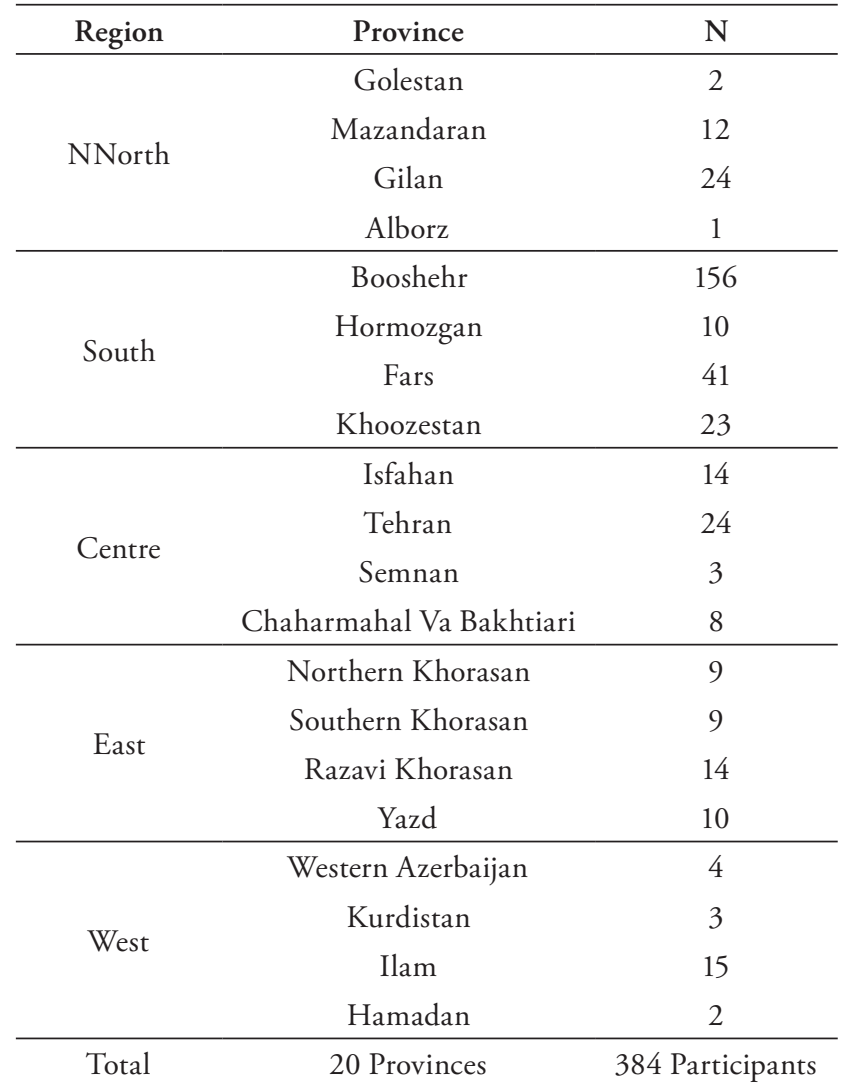

\subsection{Instruments}

The variables studied in this research were: 1) Leadership style. 2) Sociocultural attitudes. 3) Personality dimensions. 4) Situational factors. The leadership style was evaluated with the Likert Leadership Styles Standard Questionnaire (Miraftab Zadeh, Rahimi, \& Hasankhani, 2014). The sociocultural attitudes of the physical education teachers were determined with the Cultural Attitudes Questionnaire (Hofstede, 1998). The personality traits of the educators were analysed with the Five Personality
Trait Inventory (Costa \& McCrae, 2008). The situational factors of employees were assessed with the Standard Staff Readiness Questionnaire (Nedaei, Mozafari and Tondnevis, 2016).

\subsection{Data Analysis}

First of all, descriptive statistics methods such as upper limit, lower limit, average, standard deviation, frequencies and percentages were used. Kolmogorov-Smirnov test was used to determine the distribution of data. One-sample t-test was used to compare the results of this study with results of previous studies. Friedman test was also used to prioritize each of the variables of the research. Independent t-test was used to compare leadership styles of different groups. Multiple regression was used to determine the association of personality, cultural attitudes and situational factors with leadership styles. SPSS was used to carry out the data analysis.

\section{Results}

A total of $36.7 \%$ of Physical Education teachers were females and $63.3 \%$ of them were males. A total of $0.5 \%$ of them had diploma, $1.8 \%$ were undergraduate, $44.5 \%$ had B.A, $47.4 \%$ had M.A and $5.7 \%$ had PhD. Regarding marital status, $15.4 \%$ were single and $84.6 \%$ were married. According to age, $0.5 \%$ of subjects were under $20,12 \%$ between 21 and 30 years, $41.7 \%$ between 31 to 40 years, and $45.8 \%$ over 40 years of age. With regard to work experience, 19\% of participants had less than 5 years of experience, $27.6 \%$ between 5 and 10 years, $21.4 \%$ between 11 and 15 years, $7.8 \%$ between 16 and 20 years, and $24.2 \%$ more than 20 years.

Based on the results of Kolmogrov-Smirnov test, normality distribution was accepted. One-sample t-test was used to examine the status of perceived leadership style from the perspective of Physical Education teachers. In this test, the average for each of the styles is compared to the average of 3 . The results of this test are summarized in Table 2.

Table 2. Results of one-sample t-test. Perceived leadership style by Physical Education teachers.

Style

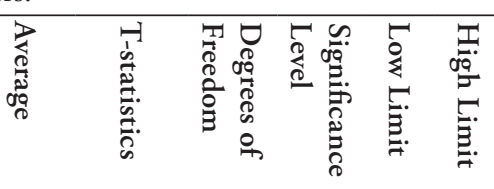

\begin{tabular}{lcccccc}
\hline $\begin{array}{l}\text { Directing leadership } \\
\text { style }\end{array}$ & 4.3 & -17.063 & 383 & .000 & -64 & .51 \\
\hline $\begin{array}{l}\text { Delegating leaders- } \\
\text { hip style }\end{array}$ & 3.38 & 12.056 & 383 & .000 & -32 & .44 \\
\hline $\begin{array}{l}\text { Coaching leaders- } \\
\text { hip style }\end{array}$ & 0.392 & 11.456 & 383 & .000 & $-33-.46$ \\
\hline $\begin{array}{l}\text { Supporting leaders- } \\
\text { hip style }\end{array}$ & 2.66 & 24.267 & 383 & .000 & $-61-.72$ \\
\hline
\end{tabular}


The Friedman test was used to prioritize each factor. The results of this test are summarized in the Table 3. According to the results of Friedman test, since the significance level obtained for the test $(<0.0001)$ is less than the acceptable level of error (0.05), it was concluded that the factors priority level is significantly different.

Table 3. Friedman test results.

\begin{tabular}{lc}
\hline Number & 384 \\
Chi- squared test statistics & 430.341 \\
Degree of Freedom & 3 \\
Significance Level of the Test & $<.0001$ \\
\hline
\end{tabular}

The results of the prioritization of the Leadership Styles of Physical Education Teachers are presented in Table 4. According to this table, the first rank is for the Directing Leadership Style and the last rank for the Supporting Leadership Style.

Table 4. Results of Prioritizing Leadership Styles of Physical Education Teachers.

\begin{tabular}{llc}
\hline Priority & Leadership Style & Average of the rates \\
\hline 4 & Supporting leadership style & 1.41 \\
2 & Delegating leadership style & 2.73 \\
3 & Coaching leadership style & 2.64 \\
1 & Directing leadership style & 3.21 \\
\hline
\end{tabular}

The results of the prioritization of the personality dimension of Physical Education Teachers are presented in Table 5. According to Table 5, the first rank is for Openness and the last rank for Extroversion.

Table 5. Results of Prioritizing the Personality Dimension of Physical Education Teachers.

\begin{tabular}{llc}
\hline Priority & Factors & Average of the rates \\
\hline 2 & Neuroticism & 3.60 \\
5 & Extroversion & 1.69 \\
1 & Openness & 4.15 \\
3 & Agreeableness & 2.83 \\
4 & Conscientiousness & 2.73 \\
\hline
\end{tabular}

SPORT TK: Revista Euroamericana de Ciencias del Deporte
The results of the prioritization of the inter-organizational applicability are presented in Table 6 . Regarding the table 6 , for physical education teachers, the first rank is related to the Collectivist cultural attitude and the last rank is related to the Matriarchal cultural attitude.

Table 6. Prioritization outcomes for inter-organizational applicability (structure of duties, authority and work team)

\begin{tabular}{llc}
\hline Priority & Factors & Average of the rates \\
\hline 4 & Matriarchy & 1.83 \\
1 & Collectivism & 3.13 \\
2 & Risk aversion & 2.86 \\
3 & Unfair power distribution & 2.18 \\
\hline
\end{tabular}

Multiple regression was used to determine the association between personality and leadership styles of Physical Education teachers. Supporting leadership style was significantly associated with agreeableness. Delegating leadership style was significantly associated with extroversion and agreeableness. Coaching leadership style was significantly associated with neuroticism and agreeableness. Directing leadership style was not significantly associated with any personality trait.

Multiple regression was used also to determine the association between the perceived cultural and social attitudes of physical education teachers with their perceived leadership style. Supporting leadership style was not significantly associated with any cultural and social attitudes. Delegating leadership style was significantly associated with uncertainty avoidance and distancing power. Coaching leadership style and Directing leadership style were significantly associated with patriarchy versus matriarchy and uncertainty avoidance.

Regarding the association between the situational factors of physical education teachers and their leadership style, there was not a significant association between any situational factor with Directing, Delegating, and Coaching leadership styles. However, supporting leadership style was significantly associated with meaningful tendency and ability of prediction.

According to the results obtained, the final model for the appropriate leadership style with regard to personality traits, sociocultural attitudes and situational factors of Physical Education teachers is suggested as follows: 


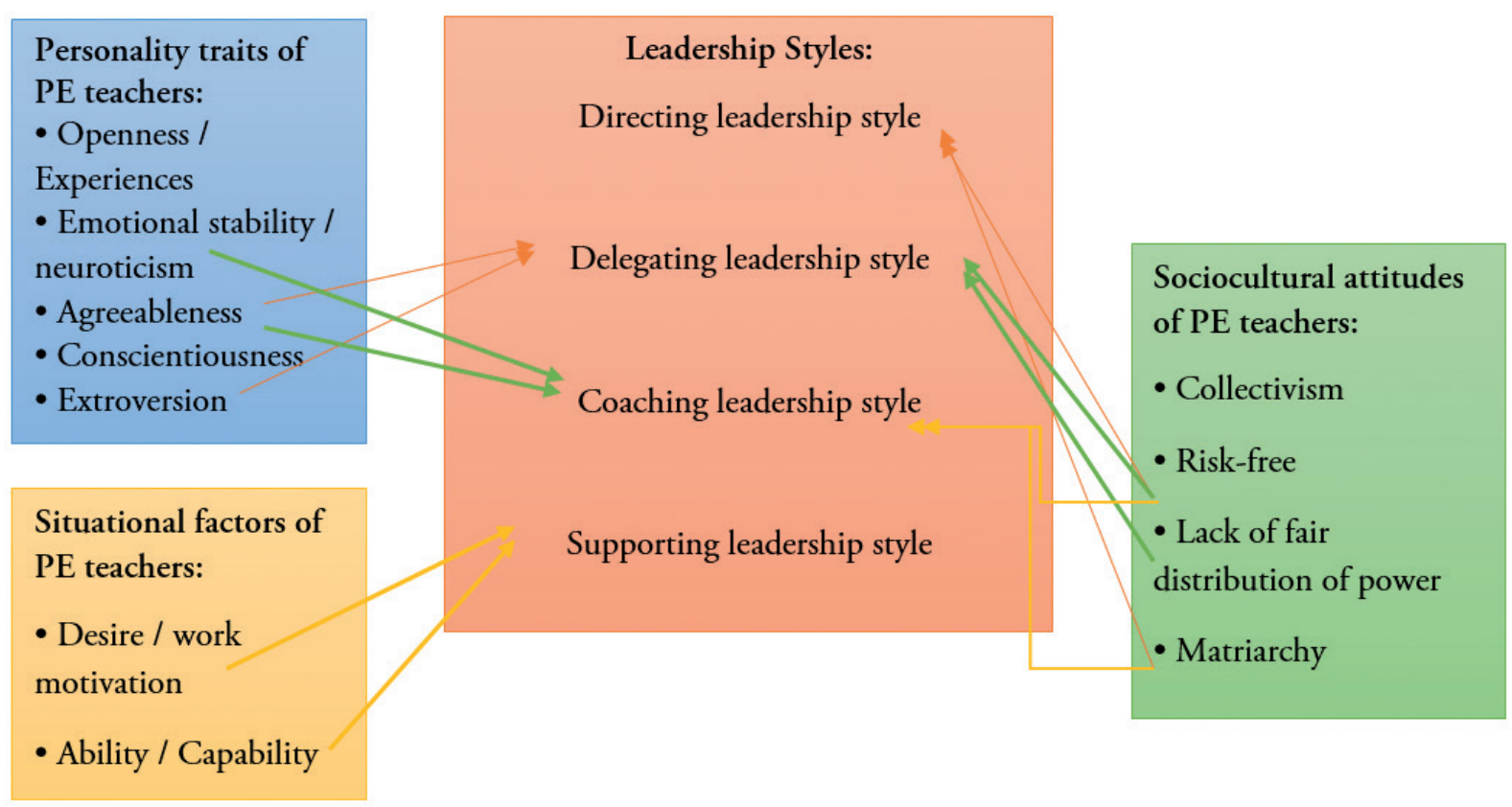

Figure 2. Final model of appropriate leadership style with regard to personality traits, sociocultural attitudes and situational factors of sports teachers

\section{Conclusion}

The final model of the appropriate leadership style with personality traits, cultural attitudes and situational factors of Physical Education teachers indicates that the most appropriate leadership styles for the Iranian Physical Education teachers were Delegating and Coaching styles, followed by Supporting and Directing styles. It is recommended to carry out new studies with the same protocol in different countries in order to compare them with the present study.

\section{References}

1. Alamdari, N. N., \& Abdi, K. (2019). The Impact of Physical Activity in the Control of Abnormal Behaviours of Iranian students. Atena Journal of Sports Sciences, 1(5), 1-11.

2. Alvani, S. M. (2001). Public Administration, Sixth Edition. Tehran (Iran): Ney Publishing. (Persian).

3. Costa, P. T., \& McCrae, R. R. (2008). The Revised NEO Personality Inventory (NEO-PI-R). In G. J. Boyle, G. Matthews, \& D. H. Saklofske (Eds.), The SAGE handbook of personality theory and assessment, Vol. 2. Personality measurement and testing (p. 179-198). Thousand Oaks, California: Sage Publications.

4. Elzami, E. (2012). Investigation on the relationship between leadership styles and organizational learning in secondary schools. Master's Thesis, Tarbiat Modares University, Tehran, Iran.

5. Fani, A. A., Hamdan, M., Khayef A., \& Ahmad A. (2010). Designing an appropriate leadership model for managing Lebanese organizations (Hospital Management). Management Research in Iran, 14(2), 65-79. (Persian).

6. Fiedler, F., \& Shimmer, M. (1990). Effective Leadership. Translation by Sohrab K. (1993). Tehran: Islamic Azad University.

7. González-Carcelén, C. M., Nicolás López, J., \& López Sánchez, G. F. (2020). Levels of physical activity in people with diabetes residing in Spain. Atena Journal of Public Health, 2(2), 1-21.

8. González-Cruz, T. F., Botella-Carrubi, D., \& Martínez-Fuentes, C. M. (2019). Supervisor leadership style, employee regulatory focus, and leadership performance: A perspectivism approach. Journal of Business Research, 101, 660-667.
9. Hamdan, M. (2009). Designing an appropriate leadership model for managing Lebanese organizations. PhD thesis, Tarbiat Modarres University, Tehran, Iran.

10. Henkel, T., \& Bourdeau, D. (2018). A field study: An examination of managers' situational leadership styles. Journal of Diversity Management, 13(2), 7-14.

11. Hersey, P., \& Blanchard, K. H. (1969). Life cycle theory of leadership. Training and Development Journal, 23(5), 26-34.

12. Hersey, P., \& Blanchard, K. H. (1977). Management of organizational behavior, 3rd Edition-Utilizing Human Resources. New Jersey: Prentice Hall.

13. Hofstede, G. (1998). Attitudes, values and organizational culture: Disentangling the concepts. Organization studies, 19(3), 477-493.

14. López Sánchez, G. F., Gordon, D., Hodgson, L., Stubbs, B., Gardner, B., \& Smith, L. (2019). The effect of the 2016 Rio de Janeiro Olympics on spectators' physical activity. Atena Journal of Sports Sciences, 1(1), 1-8.

15. Miraftab Zadeh, S. M., Rahimi, M., \& Hasankhani, M. (2014). An investigation into the effect of Likert's leadership styles on empowering Iran insurance company's staff. European Online Journal of Natural and Social Sciences, 2(3), 2466-2474.

16. Mujtaba, B. G., \& Sungkhawan, J. (2009). Situational leadership and diversity management coaching skills. Journal of Diversity Management, $4(1), 1-12$.

17. Nedaei, T., Mozafari, S. A. A., \& Tondnevis, F. (2016). Relationship between Employee's Readiness (Ability and Willingness) with Effecti- 
veness of Sport Federations. Research in Sports Management and Motor Behaviour, 6(11), 77-90.

18. Nicolás López, J., González Carcelén, C. M., \& López Sánchez, G. F. (2020). Barriers to physical activity in people with diabetes residing in Spain. Atena Journal of Public Health, 2(3), 1-20.

19. Parhizgar (1989). Human Relations in Management. Tehran (Iran): Eshraghi Publishing House. (Persian).

20. Reunanen, T., \& Kaitonen, J. (2017). Different roles in leadership styles in modern organization. In J. I. Kantola, T. Barath, S. Nazir, \& T. Andre. (Ed.), Advances in human factors, business management, training and education (pp. 251-262). Cham (Switzerland): Springer.

21. Rezaeian, A. (2001). Organizational Behavior Management, Second Edition. Tehran (Iran): SAMT Publications. (Persian).

22. Richardson, M. (2018). Stepping up: Applying situational leadership concepts to public library work with teens. OLA Quarterly, 24(2), 15-18.

23. Sami'i, M. (2010). The impact of teachers' needs on the effectiveness of leadership styles of primary school managers. Master's thesis, Ferdowsi University of Mashhad, Mashhad, Iran.
24. Sánchez-Castillo, S., Cepeda-Quintanar, S., Díaz-Suárez, A., Smith, L., López-Sánchez, G. F. (2019). Actividad física en personas con EPOC residentes en España: Diferencias según sexo y edad. Journal of Sport and Health Research, 11(Supl 1), 59-68.

25. Sánchez Castillo, S., López Sánchez, G. F., Sgroi, M., Díaz Suárez, A. (2019). Body image and obesity by Stunkard's silhouettes in 14- to 21-year-old Italian adolescents. Journal of Sport and Health Research, $11(2), 199-210$.

26. Vandayani, P., Kartini, D., \& Hilmiana, Y. A. (2015). The impact of national culture on effectiveness of situational leadership Hersey-Blanchard. International Journal of Scientific \& Technology Research, 4(7), 78-82.

27. Woods, T. B. (2019). An examination of the suitability of transactional, transformational and situational leadership theories in evaluating the role of gender in determining the leadership style: A comparison and contrast of three leadership theories. American Journal of Management Studies, 4(1), 1-11. 